DOI https://doi.org/10.36059/978-966-397-235-0-16

Riaboshapchenko A. O.,

Candidate of Legal Sciences,

Associate Professor at the Department of International

and European Law

National University «Odesa Law Academy»,

Odesa

Zhebrovska K. A.,

Candidate of Legal Sciences,

Associate Professor at the Department of International

and European Law

National University «Odesa Law Academy»,

Odesa

\title{
THE CONCEPT OF INTERNATIONAL AND EUROPEAN LEGAL STANDARDS OF HUMAN RIGHTS
}

Summary. International standards of human rights and freedoms can be considered as universally recognized provisions of international acts of binding and recommendatory nature, as well as principles of international law, which enshrine the fundamental rights of the individual, which are crucial for protecting people from illegal and unjustified actions by the state, other persons, violate or restrict these rights, as well as serve as a guide for all states in regulating and ensuring the rights of their citizens. The foundations of international human rights standards continue to evolve simultaneously with the process of forming new legal systems that declare in their constitutions the ideas of the rule of law and respect for human rights.

International human rights standards are universally recognized international legal norms that enshrine the status of the individual at the universal level and establish a list of fundamental rights and freedoms, the obligation of states to respect these rights and freedoms, and the limits of possible or permissible restrictions. International standards of human rights and freedoms are enshrined in international agreements, conventions and covenants, based on world experience and embodying current needs and trends in social issues.

International human rights standards are based on generally accepted principles such as: respect for the sovereignty of the state; 
Права людини в Україні та у зарубіжних країнах: традиції та новації

inadmissibility of interference in the internal affairs of the state; selfgovernment of peoples and nations; equality of all people and nondiscrimination; equality of rights and opportunities for men and women; respect for human rights, even in the event of armed conflict and responsibility for criminal human rights violations. The significance of these principles lies in the fact that they are the basis for the development of human rights and their enshrinement in national law, as well as a criterion for the legitimacy of the state in the field of human rights.

International human rights standards have developed gradually. Initially, only political rights were enshrined, then economic and social rights. They were specified in the national legislation of the states. However, each state must not only bring its legislation in line with its international obligations, but also take certain actions and create real conditions for guaranteeing and exercising rights.

International human rights standards are based on the rules of natural law, which include the ideals of freedom, justice and equality before the law. These norms are enshrined in the legal system of each state.

\section{Introduction}

Among the intangible values realized by most people in open democracies, human rights and freedoms remain paramount. These views are based on the liberal democratic tradition of socio-political thought, which has been developing for more than three centuries. Human dignity is the source of his rights and freedoms. Human rights are based on one undoubted value - human dignity. The problem of human rights protection is the most pressing in international law. Human rights are universal moral rights of a fundamental nature, which belong to every person in his relations with the state. Human rights are a cross-cutting theme of UN programs and strategies in areas such as peace and security, development, humanitarian assistance and economic and social issues. One of the most important achievements of the UN is the creation of a comprehensive body of human rights law - a universal code that is protected at the international level, to which any state can join and to which all people seek to implement. The United Nations has identified a wide range of internationally recognized rights and established mechanisms to promote and protect those rights and to assist States in fulfilling their commitments.

The foundations of international human rights standards continue to evolve simultaneously with the process of forming new legal 
systems that declare in their constitutions the ideas of the rule of law and respect for human rights. Doctrinal approaches to the interaction of international and national law, to the legitimacy of universal international legal standards and their role in the protection of individuals at the national level in the context of practical issues and challenges that exist at the international and national levels should now be considered. The human rights sector is constantly evolving through the development of new international and national legal instruments.

The aim of this scientific research is to study international and European human rights standards in the context of the fact that human rights issues are most important in international law, as well as the role of the UN in shaping international human rights standards.

\section{International legal standards of human rights: general principles and mechanism of compliance}

International standards of human rights and freedoms can be considered as universally recognized provisions of international acts of binding and recommendatory nature, as well as principles of international law, which enshrine the fundamental rights of the individual, which are crucial for protecting people from illegal and unjustified actions by the state, other persons, violate or restrict these rights, as well as serve as a guide for all states in regulating and ensuring the rights of their citizens.

According to P.M. Rabinovych [22], the classification of international human rights standards is carried out according to various criteria: depending on their ontic status, such standards are divided into nominal (terminological, textual), which include only the names of human rights and freedoms applied in international instruments and actual (substantive), which include recorded in these sources content and volume indicators of such rights and freedoms; by deontic status - mandatory, the implementation of which is formally necessary for the respective states and can be ensured even by the application of international political and legal sanctions, and recommendatory, which, although not formally binding, but also secured by international political sanctions (morally -political); by space (territory) actions - world (general civilization, global) and regional (in particular, continental); by the circle of addressees general (applies to all people) and specialized (addressed to members of only certain social communities, groups - for example, children, 
women, refugees); according to the subject of their establishment: standards of the UN, UNESCO, the Council of Europe, the European Union, etc. It should be noted that the above list of international human rights standards is not exhaustive.

The inclusion of international human rights standards in national legal systems in legal research is denoted by various terms: "transformation", "implementation", "harmonization", "incorporation", "adaptation", "implementation". As for the term "implementation", it was developed in international law and has become widespread in numerous resolutions of the UN General Assembly, in many international conventions and treaties. In most cases, the implementation of international law is a sphere of sovereign states that use their internal organizational and legal mechanism for this purpose. At the international level, the criteria to be met by the rule-making process in setting human rights standards are defined. An example of this is the UN General Assembly Resolution № 41/120 of December 4, 1966 "Establishment of international standards in the field of human rights" [1]. International human rights standards are understood as enshrined in international acts and documents, textually unified, functionally universal principles and norms that fix the minimum necessary and desirable content and scope of human rights, due to the achieved level of social development and establish positive obligations of states to ensure them, protection and defense, providing for their violation of sanctions of political, legal or political nature.

International standards of human rights and freedoms are enshrined in international agreements, conventions and covenants, based on world experience and embodying current needs and trends in social issues. The United Nations (UN), established in 1945, played a key role in the development of international human rights standards. It was the UN Charter that became the first multilateral international treaty in the history of international relations, which laid the foundations for the process of forming universal values of mankind and marked the beginning of a new stage in the field of protection of human rights and freedoms. In particular, paragraph "c" of Art. Article 55 of the Charter obliges states to develop international cooperation in order to promote "universal respect for and observance of human rights and fundamental freedoms for all, regardless of race, sex, language or religion." Thus, this fundamental international treaty enshrined the principle of respect and observance of human rights in the modern world community [18]. 
The main international conventions containing international standards of human rights and freedoms are: the Universal Declaration of Human Rights (1948), the Covenant on Civil and Political Rights (1966 and 1966), and the Covenant on Civil and Political Rights (1966). The Charter of Economic Rights and Duties of States (1974), the Convention for the Protection of Human Rights and Fundamental Freedoms (1950), and the European Social Charter (1961). The Catalog of Human Rights proclaimed in the Universal Declaration of Human Rights (1948), based on European values, was proclaimed universal. It expresses the values without which the normal development of society is impossible, based on the principles of freedom, the rule of law and human rights. The idea of the universality of human rights, formulated in the Universal Declaration of Human Rights (1948) and other international legal acts, was accepted as an axiom.

The provision on the universality of international legal standards was confirmed in the Vienna Declaration and Program of Action adopted at the World Conference on Human Rights (1993). The most important in the protection and observance of international standards of human rights and freedoms is the presence and effectiveness of international mechanisms for their provision. In those cases when the state mechanism is not able to ensure the realization of human rights and freedoms, international law provides for the possibility of confusion between international mechanisms and human rights.

One of the most important comprehensive international acts for the protection of human and civil rights is the Universal Declaration of Human Rights adopted by the UN General Assembly on December 10, 1948. The declaration defined a wide range of civil, political, socioeconomic and cultural rights. The text of the document reflects the natural nature of human rights, and it is proclaimed that all peoples and all states should promote the respect and protection of human rights and freedoms through national and international progressive measures. The implementation of the rights enshrined in the Universal Declaration of Human Rights and other international instruments has become a very difficult process, given the different levels of social, economic and cultural development. The two fundamental documents included in the International Bill were the International Covenants adopted by the UN General Assembly on December 16, 1966: On Political and Civil Rights and On Economic, Social and Cultural Rights. The fact that the draft Declaration and 
Covenants were drafted by the same Human Rights Commission, set up in early 1946, was a happy coincidence, as it ensured continuity and logical consistency in the content of the Declaration and Covenants and thus defined their functional relationship: purpose The Declaration consisted in the very definition of human rights, while the purpose of the Covenants was to translate international human rights norms into specific positive legal obligations of states [3].

For the first time, an individual has become a subject of international law. Under the provisions of which, all persons residing in a State party to the Covenants or having jurisdiction over that State shall be entitled to exercise the rights provided for in the Covenants without distinction as to race, color, sex, language, religion, political or other opinion. , national social origin, property, caste or other status. All member states are obliged to bring their national legislation into line with the provisions of these legal instruments. In addition, under the Optional Protocol to the Covenant on Civil and Political Rights, a citizen of any State party to the Covenant that has signed the Protocol may apply directly to the UN Human Rights Committee for protection of his rights [13].

The legal basis for the work of the UN Human Rights Committee includes the procedural rules related to its functioning and the substantive rules that it applies in the exercise of the powers vested in this international body. The analysis of the competence of the UN Human Rights Committee allows us to single out the following functions: the control function, which is to monitor the implementation of member states of their obligations under the International Covenant on Civil and Political Rights (1966); the interpretive function exercised when the Committee clarifies the content of the provisions of the Covenant and the specifics of its implementation; implementation function, which is manifested in the promotion and institutional support of the implementation of obligations under the Covenant by States parties; judicial function, which is to consider interstate disputes and individual reports of violations. The powers of the Committee include: consideration of reports of States parties to the Covenant; consideration of interstate disputes; consideration of individual reports of violations. Following the consideration of the reports of the States parties to the International Covenant on Civil and Political Rights (1966), the Committee does not take decisions binding on States, but in the practice of the Committee there are so-called general comments, 
concluding remarks and considerations. As all decisions of the UN Human Rights Committee are of a recommendatory nature, the decisions of the Committee by legal nature should be considered acts of "soft law" along with acts of international organizations, the importance of which is due to the high degree of implementation of the recommendations of this body. In its consideration of interstate disputes, the Committee may provide good offices to States parties or mediate through the establishment of a Conciliation Commission. The practice of the Committee is actively used by the International Court of Justice and the Inter-American Court of Human Rights [18].

The International Covenant on Economic, Social and Cultural Rights, adopted by the UN General Assembly on 16 December 1966, defined more specifically human rights such as the right to work, to strike, to health care, to education, to participate in cultural life, and also the rights of convicts. The realization of these rights is associated with the expansion of the paternalistic functions of the state, and depends on the level of political, economic and social development of the latter. The International Covenant on Economic, Social and Cultural Rights establishes only the standards to which the state must strive. The Committee on Economic, Social and Cultural Rights monitors the observance by States parties of their obligations under the Covenant and the level of exercise of their respective rights and responsibilities. The mandate of the Committee is set out in Chapter IV of the Covenant and ECOSOC resolutions and includes consideration of periodic reports by States on the measures they have taken and on progress towards achieving the rights recognized in the Covenant.

The development of universal and regional human rights standards takes place in complex and contradictory conditions, in which the states that form and implement such standards differ not only in their socioeconomic systems, but also in civilizational features that sometimes complicate the implementation of universal standards in all spheres of life. International standards of human rights and freedoms are established by the international community within international organizations for their provision and protection both at the international level and at the international level. The formation and normative consolidation of international standards of human rights and freedoms took place gradually at the UN level, and then at the regional level - within the regional international organizations [14].

The UN Charter of 1945 emphasizes that the organization promotes the full respect and observance of human rights and 
Права людини в Україні та у зарубіжних країнах: традиції та новації

fundamental freedoms for all, in the UN Charter imposes on states the obligation not only to respect but also to respect. The leading role of the United Nations in maintaining international peace and security, as well as in ensuring global cooperation and the development of international law, makes it of paramount importance in the field of international legal regulation of the fight against terrorism.

UN statutory bodies play an important role in ensuring respect for human rights. According to Article 7 of the UN Charter, it defines the list of the main UN bodies: the General Assembly, the Security Council, the Economic and Social Council, the Trusteeship Council, the International Court of Justice and the Secretariat; and paragraph 2, Article 7 of the Charter contains provisions for the establishment, if necessary, of subsidiary bodies within the UN. According to Art. 13 of the Charter, the UN General Assembly should promote international cooperation in the social, cultural, economic, health, and human rights and fundamental freedoms.

To implement these tasks, the UN General Assembly may adopt recommendations addressed to member countries of the Organization. Thus, in 1948, the UN General Assembly adopted the Universal Declaration of Human Rights. Among other major UN bodies, the Economic and Social Council (ECOSOC), which coordinates the UN's economic and social activities under the leadership of the General Assembly, has a special role to play in protecting human rights. human rights and fundamental freedoms for all. "This body has the right to prepare draft conventions for the General Assembly on matters within its competence, to set up commissions to carry out its functions and to carry out various activities in the field of human rights protection [25].

The leading role of the United Nations in maintaining international peace and security, as well as in ensuring global cooperation and the development of international law, makes it of paramount importance in the field of international legal regulation of the fight against terrorism. At the same time, among the six main UN bodies, the most important in terms of maintaining international peace and security and ensuring proper regulation of international relations is the Security Council, which in accordance with paragraph 1 of Art. 24 of the Charter, has the primary responsibility for maintaining international peace and security and acts on behalf of all UN members in the performance of their duties. The 15-member Security Council 
Права людини в Україні та у зарубіжних країнах: традиції та новації

focuses on specific tasks related to the maintenance of international peace and security.

In addition to the above-mentioned UN general bodies, special attention should be paid to the UN Human Rights Council as a profile body in the system of the international mechanism for the protection of human and civil rights and freedoms. This body was established in 2005 during the Summit of Heads of State and Government in New York and replaced the existing UN Commission and Human Rights Committee. The next step in the development of this body was the UN General Assembly resolution 60/251, which contains provisions on the mandate, work, composition and procedure for the election of members of the Council.

According to the resolution, the main purpose of the Council is to protect human rights and fundamental freedoms on a fair and equal basis, as well as the effective coordination and integration of human rights activities within the UN system. One of the characteristic features of international law is the existence of an extensive system of means for the peaceful settlement of international disputes, which includes both conciliatory and judicial means. Part 1 of Art. 33 of the UN Charter stipulates that the parties to the dispute must first seek to resolve the dispute through negotiation, examination, mediation, conciliation, arbitration, litigation, recourse to regional authorities and agreements. The main judicial body of the entire international community, of course, is the International Court of Justice [30].

According to Art. 96 of the UN Charter, Art. 65 of the Charter of the International Court of Justice, the UN General Assembly or the UN Security Council may request advisory opinions on any legal matter. Other UN bodies and specialized agencies, which may be authorized by the General Assembly at any time, may also request the Court's advisory opinions on legal issues arising within the scope of their activities.

The UN Charter stipulates that each of the main UN bodies may establish different specialized agencies or units to perform its duties. The options of any subsidiary body of the United Nations are limited. They perform the work strictly defined by their constituent act, respectively, the legal status and importance of UN subsidiary bodies are different. Some of them are practically intergovernmental organizations, and others are autonomous intergovernmental bodies. There are many UN organizations and agencies that operate and carry out a variety of work on specific issues, such as: the International 
Права людини в Україні та у зарубіжних країнах: традиції та новації

Labor Organization, the International Atomic Energy Agency (IAEA), the Food and Agriculture Organization of the United Nations, UNESCO, the United Nations Educational and Scientific Organization. and Culture), UNIDO (United Nations Industrial Development Organization), the World Bank and the World Health Organization (WHO). It is through these agencies that the UN does most of its humanitarian work.

Monitoring of human rights within the UN is exercised by all its major bodies, including: UN Security Council; UN General Assembly; UN Economic and Social Council. The General Assembly is the main body of the United Nations. According to it. 1 (6) of Art. 13 of the UN Charter, it organizes research and makes recommendations aimed at "promoting the enjoyment of human rights and fundamental freedoms for all, regardless of race, sex, language or religion." According to the UN Charter, along with the General Assembly, the responsibility for carrying out the organization's human rights functions rests with the Economic and Social Council (ECOSOC), which operates under the authority of the UN General Assembly.

ECOSOC is the central body for guidance and coordination in the field of human rights, authorized to: in accordance with paragraph 2 of Art. 62 of the UN Charter, "to provide recommendations to promote respect for and observance of human rights and fundamental freedoms for all"; "prepare for submission to the General Assembly draft conventions" (paragraph 3 of Article 62 of the UN Charter); "convene international conferences" (paragraph 4 of Article 62 of the UN Charter).

To perform the functions assigned to the Economic and Social Council, it establishes special commissions (Article 68 of the UN Charter). In accordance with this article, a Commission on Human Rights, a Commission on the Status of Women and a Sub-Commission on Prevention of Discrimination and Protection of Minorities have been established, focusing exclusively on human rights issues. The UN-established system of human rights protection is based on the work of permanent institutions, the foundations of which are enshrined in various international human rights conventions [11]. This is the Office of the High Commissioner for Human Rights, which includes the Human Rights Council, which replaced the Human Rights Commission in 2006. These changes were made to ensure the continuity and continuity of these bodies, as well as to limit their 
politicization. The protection of human rights in the UN system is divided into two main parts.

The statutory bodies include: Human Rights Council (until 2006 Commission on Human Rights); special procedures of the Human Rights Council; the procedure for reviewing complaints to the Human Rights Council; Universal Periodic Review a mechanism for reviewing human rights information in all UN member states, which is part of the structure of the Human Rights Council and provides an opportunity for each country to inform about the measures taken to improve the human rights situation and to fulfill its obligations in this area. The Human Rights Council is an independent body separate from the Office of the High Commissioner for Human Rights, in accordance with the mandates issued by the General Assembly [18].

However, OHCHR provides for meetings and subsequent meetings of the Human Rights Council. The Council consists of 47 UN member states. This UN statutory human rights body has the authority to end human rights abuses, eliminate inequality and discrimination, protect the most vulnerable, and prosecute offenders. "Special procedures" is the general name of the mechanisms provided by the Commission on Human Rights and adopted by the Human Rights Council to address specific situations in the country or thematic issues in all parts of the world. Special procedures are either an individual (special representative or independent expert) or a working group. The mandates of the special procedures are given to outstanding, independent experts who work on a voluntary basis and are appointed by the Council. The mandate of special procedures involves studying, monitoring, advising and informing the public about the human rights situation in individual countries or territories (country mandates) or about mass human rights violations around the world (thematic mandates) [25].

All special procedures report to the Human Rights Council on the results of their activities and recommendations. Sometimes they are the only mechanism that notifies the international community of existing human rights problems, as they can deal with situations in any part of the world, regardless of whether a state has ratified a human rights instrument. As of August 1, 2017, there are 44 thematic mandates and 12 country mandates. The human rights treaty bodies are organized in accordance with separate treaties, which distinguishes them from the UN statutory human rights bodies, which are established on the basis of the UN Charter (for example, the 
Права людини в Україні та у зарубіжних країнах: традиції та новації

Human Rights Council, the General Assembly, the Security Council). When a state ratifies one of these treaties, it enters into a legal obligation to incorporate the provisions of the human rights treaty into its national law [10].

The UN human rights treaty bodies are committees made up of independent human rights experts. It is their responsibility to monitor and control how the "States Parties" (in the States that have ratified the Treaty) implement its provisions. Nine of these committees monitor the implementation of UN human rights treaties by States parties, and the tenth, the Subcommittee on Prevention of Torture, established under the Optional Protocol to the Convention against Torture, inspects places of detention in States parties to the Optional Protocol [11].

The Human Rights Committee monitors compliance with the International Covenant on Civil and Political Rights. The Committee on Economic, Social and Cultural Rights (CESCR) monitors compliance with the International Covenant on Economic, Social and Cultural Rights. The Committee on the Rights of the Child (CRC) monitors compliance with the Convention on the Rights of the Child and the Additional Protocols (on children in military conflict, trafficking in children and child pornography, and the establishment of a grievance mechanism). The Committee on the Elimination of Discrimination against Women (CEDAW) monitors compliance with the Convention on the Elimination of All Forms of Racial Discrimination against Women. The Committee on the Elimination of Racial Discrimination (CERD) monitors compliance with the International Convention on the Elimination of All Forms of Racial Discrimination. The Committee against Torture (CAT) monitors compliance with the Convention against Torture and Other Cruel, Inhuman or Degrading Treatment or Punishment and the Optional Protocol on Persons Imprisoned. The Committee for the Protection of the Rights of Migrant Workers (CMW) monitors compliance with the International Convention on the Protection of the Rights of All Migrant Workers and Members of Their Families. The Committee on the Rights of Persons with Disabilities (CRPD) monitors compliance with the Convention on the Rights of Persons with Disabilities. The Committee on Enforced Disappearances (CED) monitors compliance with the International Convention for the Protection of All Persons from Enforced Disappearance.

An important element in the mechanism of monitoring compliance with international human rights standards within the UN belongs to 
specialized agencies, bodies, programs created on the basis of intergovernmental agreements. The scope of their control activities is limited, and is aimed mainly at respecting human rights in the economic, social spheres, in the field of culture, education, health care. Among such institutions are, first of all, the International Labor Organization (ILO) and UNESCO. The International Labor Organization (ILO) was established in 1919 and became its first specialized agency since the United Nations. According to the ILO Charter, its purpose is to promote universal and lasting peace on the basis of social justice by improving working conditions [24].

A feature of the ILO is the tripartite representation, in which, along with governments, trade unions and business organizations of member countries participate. The ILO's monitoring system includes two mechanisms: a regular monitoring system, which consists of examining periodic reports on measures taken to implement the provisions of conventions ratified by the state; special procedures.

UNESCO is a specialized UN body for education, science and culture and seeks to establish peace through international cooperation in these areas. The procedure for monitoring the observance of human rights within UNESCO differs significantly from all other procedures provided for by other specialized bodies. Courts have been established at the universal level (UN International Court of Justice, International Tribunal for the Law of the Sea) and at the regional level (European Court of Human Rights, European Court of Justice, etc.). International judicial institutions of universal and regional level play a key role in the mechanism of human rights protection. The main universal-level judicial body established within the United Nations is the United Nations International Court of Justice, which is responsible for the administration of international justice. Its composition and competence are defined by the UN Charter and the Statute of the International Court of Justice [1].

\section{European human rights protection system}

Today, the most effective system of human rights protection is the European system of human rights protection, which is the result of long historical development. The modern European system of human rights protection is the only system of principles, norms and mechanisms operating in the European legal space that ensure the protection of human rights. Cooperation in the field of human rights in Europe is carried out in the framework of: Council of Europe; the 
Права людини в Україні та у зарубіжних країнах: традиції та новації

European Union; Organization for Security and Co-operation in Europe (hereinafter - the OSCE). The protection of human rights within the Council of Europe is carried out through the development of conventions, resolutions and recommendations for monitoring the observance of treaty provisions by member states through a system of statutory and non-statutory bodies, including conventions [5].

The European system of human rights protection includes, first of all, the effect and guarantees of the norms of various European conventions on human rights, as well as the direct activity of the Council of Europe, its supervisory bodies, especially the ECtHR, which ensure compliance with European human rights conventions. In Western Europe, such standards have been in place for decades. The European system of human rights protection is based on uniform standards.

The European system of human rights protection includes: European convention norms in the field of human rights; effective application of the norms of European conventions by the member states of the Council of Europe; activities of European structures (Council of Europe and its supervisory bodies) related to ensuring the norms of European conventions, implementation of these norms by the national legal systems of the member states of the Council of Europe, as well as setting precedents in the field of human rights (mainly the European Court of Justice) [6].

The first regional human rights instrument is the Convention for the Protection of Human Rights and Fundamental Freedoms, adopted in 1950, the preamble of which states that "governments of European countries which share common views and have a common heritage of political traditions and ideals, respect for freedom and rule of law, have taken the first steps towards ensuring certain rights enshrined in the Universal Declaration of Human Rights".

The European Convention protects, first and foremost, civil and political rights, including: the right to life (Article 2); prohibition of torture (art. 3); prohibition of slavery and forced labor (Article 4); the right to liberty and security (art. 5); the right to a fair trial (Article 6); inadmissibility of punishment without a legal basis (Article 7); the right to respect for private and family life (Article 8); freedom of thought, conscience and religion (Article 9); freedom of expression (Article 10); freedom of assembly and association (art. 11); the right to marry (Article 12); the right to an effective remedy (Article 13); 
prohibition of discrimination (Article 14). Thus, the European Convention enshrined the whole set of universal values [7].

Fundamental European values are presented in the form of a triad "the rule of law, democracy, human rights. The core of European values are liberal fundamental human rights and freedoms, democratic principles of government, as well as the rule of law and the welfare state. As a combination of liberal and democratic ideas, European values are referred to as "liberal-democratic". The latter became the principles of functioning of state and political institutions of modern European countries and the European Union. European values are not only a general abstract concept, but also have a concrete practical expression in the form of legal norms enshrined in a number of basic documents of the Council of Europe and the European Union (Convention for the Protection of Fundamental Freedoms, etc.), Treaty on the Functioning of the European Union, etc.) [8].

The fundamental basis of European values are the rights and freedoms of each individual and the equality of all before the law. These legal values have been transformed in the legal systems of European countries. States wishing to become members of the Council of Europe must, first of all, ratify this fundamental human rights law [15]. The European system of human rights protection is the most effective in this area, as the goals it has set for itself are not only universally recognized, but also constantly evolving and complementary.

The European Convention on Human Rights is a dynamic phenomenon. To this end, additional Protocols have been developed and are being developed through the interpretation of its provisions by the European Court of Human Rights. Under case law, the Court decides how the provisions of the European Convention may be interpreted for a given period of time. Article 6 of the EU Treaty clearly states: "The EU is founded on the principles of liberty, democracy, respect for human rights and fundamental freedoms, and the rule of law; these principles are shared by all Member States" [16].

The basic values of the EU are reflected in the Charter of Fundamental Rights of the European Union. In the Charter, the rights and freedoms of EU citizens emerged as the values of all EU member states, on which the activities of the EU institutions are based, as stated in the preamble of the document: "The peoples of Europe on the basis of common values... The European Union promotes the preservation and development of these common values while respecting the diversity of cultures and traditions of the peoples of Europe, as well as the national identity of Member States 
Права людини в Україні та у зарубіжних країнах: традиції та новації

and the organization of their public authorities at national, regional and local levels [20].

In total, the Charter of Fundamental Rights of the European Union consists of 54 articles, which are divided into seven sections. The first six articles are fundamental values, and the last, seventh chapter, regulates and explains the application of the document [21]. Thus, the basic values defined and recognized by the European community and enshrined in the document include:

- dignity (Chapter 1, Articles 1-5): rights and guarantees that ensure the dignified existence of the human person in society: the right to life, the right to personal inviolability, prohibition of torture and other cruel, inhuman or degrading treatment, punishment, freedom from slavery and servitude;

- freedoms (Chapter 2, Articles 6-19): fundamental civil and political freedoms enshrined in the European Convention on Human Rights: the right to liberty and security of person, respect for private and family life, protection of personal information, freedom of thought, conscience and religion, freedom of expression and freedom of information, freedom of assembly and association, and certain social rights: the right to education, freedom of professional activity and the right to work, freedom of enterprise, property rights;

- equality (Chapter 3, Articles 20-26): equality of rights, nondiscrimination, cultural, religious and linguistic diversity, equal rights between men and women, protection of the rights of the child and the elderly; solidarity (section 4, pp. 27-38): this section contains certain labor rights and reflects some provisions of the European Social Charter, which has already become part of EU law: the right of workers to receive information, the right to negotiate and collective action, the right to services on employment, protection in case of illegal dismissal, fair and equal working conditions, Art. 109 social security and social assistance, health care, environmental protection and consumer rights;

- citizenship (Chapter 5, Articles 39-46): active and passive suffrage in elections to the European Parliament and municipal elections, the right to good administration, the right of access to documents, the right to appeal to the EU Ombudsman, freedom of movement and residence, diplomatic and consular protection;

- justice (Chapter 6, Articles 47-50): enshrines not so much rights as guarantees of individual rights, mainly in criminal proceedings: the right to effective legal protection and access to an 
impartial tribunal, the presumption of innocence and the right to protection, the rule of law and compliance of the punishment with the committed crime. In general, the documents of the Council of Europe and the European Union, which are dedicated to ensuring the rights and freedoms of the individual and, in particular, the "Charter of Fundamental Rights of the European Union", are based on the constitutional traditions of European countries and their international obligations", which was adopted by the UN General Assembly on December 10, 1948.

\section{Peculiarities of restriction of international human rights and freedoms}

One of the urgent issues today is the guarantee and protection of human and civil rights both in one country and around the world. This is facilitated by both national and international law. It should be noted that in order to ensure respect for human and civil rights and freedoms, the state and the international community must limit the rights of one group of persons so as not to violate the rights of another group. Thus we can talk about the lawful restriction of rights and freedoms. Restrictions are allowed for most rights and freedoms.

However, the authorities should not restrict human rights solely on their own volition. Such restrictions must comply with the requirements of international law. In the doctrine there is no single understanding of the concept of "restriction of human rights and freedoms", there are different views on this issue, as well as on the classification of restrictions, their procedural and material components. At the level of international legal acts, there is also the use of different terminology [26].

In the Universal Declaration of Human Rights, the International Covenant on Economic, Social and Cultural Rights, the term "restriction" is used, in the International Covenant on Civil and Political Rights - "waiver of obligations", in the American Convention on Human Rights - "suspension of guarantees", in the European Convention for the Protection of Human Rights and Fundamental Freedoms - "restrictions" and "derogation from their obligations". The right to derogate is the ability of a state to derogate from certain of its international human rights obligations during emergencies and to suspend national legislation. The derogation cannot be applied to the whole range of guaranteed rights and freedoms, as a rule, the right 
Права людини в Україні та у зарубіжних країнах: традиції та новації

to life, the prohibition of torture, the prohibition of slavery, and no punishment without law are reserved [28].

In accordance with Part 2 of Art. 29 of the Universal Declaration of Human Rights "in the exercise of his rights and freedoms, everyone shall be subject only to such limitations as are prescribed by law solely for the proper recognition and respect of the rights and freedoms of others and for the just requirements of morality, public order and general welfare in a democratic society."

International Covenant on Civil and Political Rights Art. 4: "In a state of emergency in a state in which the life of the nation is endangered and officially declared, the States Parties to the present Covenant may take measures to derogate from their obligations under the present Covenant only to the extent that it is dictated by the severity of the situation, provided that such measures are not incompatible with their other obligations under international law and do not result in discrimination solely on the grounds of race, color, sex, language, religion or social origin... Any State, a Party to the present Covenant and exercising the right of withdrawal shall immediately inform the other States Parties to the present Covenant, through the Secretary-General of the United Nations, of the provisions from which it has withdrawn and the reasons for such a decision. . The date on which it terminates such withdrawal must also be notified through the same intermediary." [27]

Additional grounds for restricting specific rights are also established (for example, in Articles 9, 12, 18, etc.). At the same time, we consider it necessary to emphasize that the provisions of international normative legal acts established by the abovementioned norms on non-conflict with other obligations under international law indicate the impossibility of their implementation, as other international legal acts, in particular the Universal Declaration of Human Rights of December 10, 1948 and the International Covenant on Economic, Social and Cultural Rights of December 16, 1996, did not establish the admissibility of restrictions on human and civil rights and freedoms in the event of a state of emergency or martial law. Thus, the formal grounds for restricting human and civil rights and freedoms are the results of the legitimacy of law-making and law enforcement activities of the state in the field of adoption of regulations on their form, content, procedure, level of stability and effectiveness of legal regulation [17]. 
The main requirements relating to the formal grounds for restriction of human and civil rights and freedoms are: an indefinite range of entities to which certain restrictions apply; clarity, stability, predictability, accessibility and compliance with other obligations under international law, the procedure for adoption, as well as international regulations. European Convention on Human Rights and Fundamental Freedoms Art. 15: "In time of war or other public danger threatening the life of the nation, any High Contracting Party may take measures derogating from its obligations under this Convention only to the extent required by the urgency of the situation and subject to that such measures do not conflict with its other obligations under international law ... Any High Contracting Party, exercising this right to withdraw from its obligations, shall keep the Secretary General of the Council of Europe fully informed of the measures and reasons taken by their use. It shall also notify the Secretary General of the Council of Europe of the time when such measures have ceased to apply and the provisions of the Convention are fully applied again." [19]

The significance of the European Convention of 1950 is that it specified and expanded the restrictions, classifying them into general and special. The general restrictions (Article 15) largely repeat the criteria set out in the Universal Declaration. Special rights and freedoms such as the right to inviolability of the person, home and correspondence, the right to freedom of peaceful assembly and association, the right to freely use one's property, the right to freedom of choice of residence, the right of foreigners to reside and inadmissibility expulsions are an innovation of the European Convention and were subsequently used in the International Covenant on Civil and Political Rights.

The development of the provisions of the European Convention on the Lawful Restriction of Human Rights and Freedoms has been carried out in the framework of the case law of the European Court of Human Rights. The Court develops an autonomous interpretation of the categories governing derogations by Member States. Thus, in Handyside v United Kingdom, the Court found it justified to restrict freedom of expression, stating that States had a wide margin of discretion in these matters. The applicant, Richard Handyside, owner of Stage 1, had acquired the rights to the Little Red Textbook, which contained a section on sex. Handyside distributed several hundred copies of the book along with a press release to national and local newspapers, educational and medical journals. He also advertised the 
book. It has been the subject of extensive press comments, both favorable and unfavorable. On April 8, a magistrate's court handed down two verdicts against Handiside for possession of obscene books and for publishing them. He stopped distributing the book and accordingly advised bookstores, but by that time about 17,000 copies were already in circulation. On July 1, 1971, he was convicted of a felony and fined $€ 25$.

The ECtHR, using the doctrine of discretion, recognized that the interference with the freedom of expression of Handyside's views was simultaneously established by law, had a legitimate aim and was necessary in a democratic society, thus there was no violation of Article 10 of the ECHR. In the case of Muller and Others v. Switzerland stated the need for a dynamic interpretation of the category of public morality and the restrictions imposed to protect it. Josef Felix Müller and nine other artists painted paintings depicting fellatio, sodomy, and sex between humans and animals at the former Great Seminary in Friborg. A complaint against the artists was filed on the grounds that the paintings were obscene and a fine was imposed as a result of the criminal proceedings [31].

The ECtHR considered defining the word "obscene", recognized the concept of ever-changing sexual morality, and found no violation of the Convention by the Swiss authorities, finding the fine justified. International legal acts allow for the possibility of restricting rights in relation to certain categories of persons, taking into account their special status, the specifics of professional activity, and so on. Thus, the possibility of restricting the rights and freedoms of law enforcement officers is provided for in a number of international documents. In particular, paragraph 2 of Article 22 of the International Covenant on Civil and Political Rights provides that this article shall not preclude the imposition of legal restrictions on the exercise of the right of everyone to freedom of association with others, including the right to form and join trade unions for members in the armed forces and police [32].

A similar provision is contained in the European Convention for the Protection of Human Rights and Fundamental Freedoms (paragraph 2 of Article 11), adding to the military and police also persons who are members of public administration. The International Covenant on Civil and Political Rights contains a separate provision that is directly related to restrictions on the rights of convicts. Part 3 of Art. 10 stipulates that the penitentiary system should provide for 
such treatment, the key purpose of which should be correction and social rehabilitation [23].

This principle stipulates that persons deprived of their liberty may not be subjected to any treatment or restriction other than the result of the restriction of their liberty, and that persons deprived of their liberty enjoy all the rights set forth in the Covenant subjects only those restrictions that are inevitable in a closed environment. Convicts, like free citizens, enjoy the protection of the European Convention and all the rights provided by it. However, although the standards of convention law must be applied without distinction as to the status of the individual, the Court's case-law is ambiguous as to the specificity of their application in convicted cases. A special place in the development of the case law of the European Court of Human Rights is occupied by the doctrine of the so-called inevitable restrictions on the rights of the person to whom prisoners are subjected. It presupposes that there are certain restrictions that follow from the legal status of a person.

\section{Conclusions}

In the modern world, the protection and observance of fundamental human and civil rights and freedoms have ceased to be the competence of a particular country, but have become a matter for the entire international community, as it has long been a more important task for many countries. Due to the increased concern and attention of the international community to these issues at various times, authoritative international organizations have adopted a number of declarations, conventions, charters. International human rights law is considered to be an international standard, as it is developed on the basis of customary norms formed by the recognition by States of the legal force of rules of conduct promulgated by the UN General Assembly in the form of declarations or recommendations. The founding members of the United Nations have committed themselves to international cooperation to promote universal respect for and observance of human rights and fundamental freedoms. International human rights standards are universally recognized international legal norms that enshrine the status of the individual at the universal level and establish a list of fundamental rights and freedoms, the obligation of states to respect these rights and freedoms, and the limits of possible or permissible restrictions. 
Today, the most effective system of human rights protection is the European system of human rights protection, which is the result of long historical development. The modern European system of human rights protection is the only system of principles, norms and mechanisms operating in the European legal space that ensure the protection of human rights. Cooperation in the field of human rights in Europe is carried out in the framework of: Council of Europe; the European Union; Organization for Security and Co-operation in Europe (hereinafter - the OSCE). The protection of human rights within the Council of Europe is carried out through the development of conventions, resolutions and recommendations for monitoring the observance of treaty provisions by member states through a system of statutory and non-statutory bodies, including conventions.

One of the urgent issues today is the guarantee and protection of human and civil rights both in one country and around the world. This is facilitated by both national and international law. It should be noted that in order to ensure respect for human and civil rights and freedoms, the state and the international community must limit the rights of one group of persons so as not to violate the rights of another group. Thus we can talk about the lawful restriction of rights and freedoms. Restrictions are allowed for most rights and freedoms.

\section{References:}

1. Бурлак О.В. Міжнародні стандарти щодо захисту i заохочення прав людини : монографія. Івано-Франківськ : Симфонія форте, 2012. 212 с.

2. Гом'єн Д. Кроткий путівник Європейською конвенцією 3 прав людини. Київ : Фенікс, 2006. 192 с.

3. Гусейнов Л.Г. Международные обязательства государств в сфере прав человека : монография. Баку, 1998. 188 с.

4. Денисова А.М. Правові обмеження: поняття, види, функції. Часопис Київського університету права. 2011. № 2. С. 51-55.

5. Джевіцкі К. Європейська система захисту прав людини : навчальний посібник. Одеса, 2005. 98 с.

6. Дудаш Т.І. Практика Європейського суду з прав людини : навчальний посібник. Київ : Правова єдність, 2014. 488 с.

7. Європейська конвенція з прав людини: основні положення, практика застосування / наук. ред. О.Л. Жуковська. Київ : ВІПОЛ, $2004.960 \mathrm{c}$. 
8. Європейське право: право ЄС : підручник / за заг. ред. В.І. Муравйова. Київ : Ін Юре, 2015.

9. Захист прав людини. Рішення Європейського суду з прав людини : збірник судової практики. Київ : Юрінком Інтер, 2014. $761 \mathrm{c.}$

10. Кавун В.Ф. Механізми міжнародного контролю у сфері прав людини : дис. ... канд. юрид. наук : 12.00.11. Київ, 2008. 214 с.

11. Карташкин В.А. ООН и международная защита прав человека в XXI в. : монография. Москва : Норма : Инфра-М, 2015. $176 \mathrm{c.}$

12. Карташкин В.А. Универсализация прав человека и традиционные ценности человечества. Современное право. 2012. № 8. С. 3-9.

13. Лукашева Е.А. Универсальные стандарты прав человека и цивилизационные традиционные нормы. Право Украины. 2011. № 5/6. С. 39-55.

14. Луковская Д.И. Понятие прав человека: многообразие подходов. Проблемы универсальности прав человека. История государства и права. 2007. № 12. С. 33-35.

15. Майбутнє Європейського суду з прав людини / гол. ред. П.М. Рабінович. Львів : Сполом, 2013. 56 с.

16. Манукян В.И. Европейский суд по правам человека: право, прецеденты, комментарии : научно-практическое пособие. Киев : Истина, 2007. 368 с.

17. Мельник К.Ю. Обмеження прав особистості як наслідок володіння спеціальним правовим статусом. Право і Безпека. 2005. Т. 4. № 3. С. 123-127.

18. Мицик В.В. Права людини у міжнародному праві: міжнародно-правові механізми захисту : підручник. Київ : Промені, 2010. 722 с.

19. Назаров В.В. Вплив рішень Європейського суду 3 прав людини на вдосконалення стандартів обмеження прав людини. Європейські перспективи. 2011. № 1. URL: http://www. nbuv. gov. ua/portal/Soc_Gum/Evp/2011_1_1/ Nazarow. Pdf.

20. Пастухова Л.В. Європейський механізм забезпечення прав людини. Сімферополь : Таврія, 2009. 224 с.

21. Практика Європейського суду 3 прав людини: загальнотеоретичні дослідження / гол. ред. П.М. Рабінович. Львів, 2009. 150 c. 
22. Рабінович П.М. Міжнародні стандарти прав людини: властивості, загальні поняття, класифікація. Вісник Національної академії правових наук України. 2016. № 1. С. 19-24.

23. Рабінович П.М. Здійснення прав людини: проблеми обмежування (загальнотеоретичні аспекти) : монографія. Львів : Астрон, 2001. 108 c.

24. Рада ООН з прав людини. Постійне представництво України при відділенні ООН та інших міжнародних організаціях у Женеві. URL: http://geneva.mfa.gov.ua/ua/ukraine-io/human-rights.

25. Руднєва О.М. Теоретичні проблеми класифікації міжнародних стандартів прав і свобод людини. Бюлетень Міністерства юстиції України. 2010. № 9. С. 32-42.

26. Стрекалов А.Є. Міжнародно-правові стандарти щодо обмеження основних прав і свобод людини і громадянина. Актуальні проблеми права: теорія і практика. 2012. № 25. C. 507-513.

27. Фігель Ю.О. Класифікація обмежень прав людини. Вісник Львівського торговельно-економічного університету. Юридичні науки. 2016. Вип. 3. С. 79-87.

28. Фігель Ю.О. Теоретичні аспекти обмеження прав людини. Вісник Національного університету «Львівська політехніка». Юридичні науки. 2016. № 837. С. 357-361.

29. Хартия Европейского Союза об основных правах: комментарий / под ред. С.Ю. Кашкина. Москва : Юриспруденция, 2001.208 c.

30. Честнов И.Л. Универсальны ли права человека. Известия высших учебных заведений. Правоведение. 1999. № 1. С. 73-82.

31. Шевчук С. Концепція позитивних обов'язків держави у практиці Європейського суду з прав людини. Право України. 2010. № 2. С. 55-59.

32. Шевчук С. Судовий захист прав людини: практика Європейського суду з прав людини. Київ : Реферат, 2006. 829 с. 